\title{
Study Of Role Of Digitization In Sustainable Business In Auto Industry In India Using Thematic Content Analysis, Spearman Analysis And Review Of Literature.
}

\author{
${ }^{1}$ Prakash D.Wagh., ${ }^{2}$ Dr.Ajim Shaikh. \\ ${ }^{1}$ Research scholar. MITADT University Pune. \\ ${ }^{2}$ Guide. MITADT University Pune.
}

Article History: Received:11 January 2021; Accepted: 27 February 2021; Published online: 5 April 2021

\begin{abstract}
Progress in digital technologies and Cyber physical technologies in last one decade has created immense opportunities for business firms and companies to adopt sustainable practices in their end to end business cycle. This is helping business to conserve the various resources like energy, material ,manual efforts, water and contributing to lower cost of goods sold ,ultimately making the balance sheet and profit and loss account green and healthy. The consumer and NGO pressures, Government rules and regulations and depleting resources is also acting as a trigger for businesses to adopt sustainability. Digitization is helping companies in achieving the sustainability aspect in their operations ,supply chain and other parts of the business. This paper is based on the interaction and interviews with 40 business leaders from Automobile industry in India during the last 2 years and literature study of digitization and sustainability goals and other related research articles. The interview output was analyzed using thematic sematic analysis (TMC) and collaborated with finding from review of literate. The study concluded that there is enough positive and significant relationship between Digitization and sustainability ( Sustainable business) in Auto industry in India.
\end{abstract}

Keywords : $\quad$ Digitization ,Sustainability, Green , Environment, Automobile , Patterns ,Themes ; Industry 4.0 , Conservation of resources

Preface : in 1990's we saw emergence of Business process reengineering (BPR), Just in time (JIT), Kanban ,Total productive maintenance and kaizen as some of the leading business or enterprise wise business initiatives. Current climate change, ozone layer depletion, generation of waste and pollution is calling for sustainability initiative to save the overall ecosystem for the betterment of mankind. Sustainability is also a philosophy like Total productive maintenance, Total quality management and its adoption enterprise wise is as easy as of those initiatives. The internet revolution, Automation and energy efficient machine, Industry 4.0,Blockchain, Machine learning ,Augmented reality, virtual reality, cloudification and many other digital technologies are helping businesses to adopt Sustainability in their operations. Sustaibaility with digitization is a creating agile ;productive and safe workplace as well as eco friendly product and services for empowered customers.

Objective : To understand and review of sustainability adoption by Automobile industry in their operations using digital technology .The study was limited to Automobile manufacturers ( 4-wheeler cars in India).

Methodology : The Methodology used was unstructured interview with 40 leaders supported by relevant review of literature. The analysis of data was done using a mixed methodology consisting of :

- Thematic Analysis to arrive at the critical variables and thematic relationship.

- Spearman statistical analysis to statistically prove the relationship among the variables.

We consider this Hybrid methodology to be unique in analyzing the unstructured interview data, thematic analysis shows the prominent variables with relationship probability while Spearman Co-efficient establishes statistically the relationship. This leaves no doubt on outcomes or conclusion as thematic analysis is supported by statistical analysis .

The subject size for unstructured interview was 40 and consisted of :

Table 1 : Segment and interviews

\begin{tabular}{|l|l|l|}
\hline Segment & Designations of the candidate & No. of Leaders interviewed \\
\hline Entry level passenger cars & $\begin{array}{l}\text { Chief marketing Manager ,Sales } \\
\text { manager ,Production Manager; IT } \\
\text { head }\end{array}$ & $\begin{array}{l}\text { 10( Random chance occurrence } \\
\text { during business visit) }\end{array}$ \\
\hline Sedan Passenger Cars & $\begin{array}{l}\text { SCM Manager,Production } \\
\text { Manager,EHS Head ,Sales } \\
\text { engineer; IT Manager }\end{array}$ & $\begin{array}{l}12 \text { ( Random chance occurrence } \\
\text { during client visits) }\end{array}$ \\
\hline Mini SUV & $\begin{array}{l}\text { Production executive ,Logistics } \\
\text { manager, IT head, DGM -SCM }\end{array}$ & $\begin{array}{l}\text { 8 (Random chance occurrence } \\
\text { during client visits) }\end{array}$ \\
\hline
\end{tabular}


Study Of Role Of Digitization In Sustainable Business In Auto Industry In India Using Thematic Content Analysis, Spearman Analysis And Review Of Literature.

\begin{tabular}{|l|l|l|}
\hline SUV & $\begin{array}{l}\text { Sales executive ,dealers ,service } \\
\text { station executive, Factory head }\end{array}$ & $\begin{array}{l}8 \text { (Discussion during proposal } \\
\text { defense) }\end{array}$ \\
\hline Luxury cards & $\begin{array}{l}\text { Dealer ,service head, sales } \\
\text { executive,IT manager }\end{array}$ & $\begin{array}{l}\text { 2 (chance occurrence during } \\
\text { accompanying the client visit) }\end{array}$ \\
\hline
\end{tabular}

Randomness in this unstructured discussion and interviewed helped to remove the bias and typical safeguarded answers from client executives. Moreover, most of these visits in last 2 year to client place /office/Factories were for Presales ,client relationship and proposals not related to sustainability. The visits were more related to ERP implementation, but this opportunity was used to gauge the sustainability initiatives going on in the organization from strategy to execution.

The input from these unstructured reviews were followed by review of literature on digitalization and sustainability. The qualitative study was done with the sole aim of checking the importance businesses are giving to sustainability angles and the various initiave goings in sustainability areas using digitization.

\section{Thematic content analysis (TCA) Methodology}

TCA as it is known in qualitative data analysis is a well-known technique for converting the open interview /unstructured interview from the participants into logical and structural analysis. While the process of labelling ,coding and themes can be achieved using simple tools like excel, there are special software's like Altos and freeware to analyses and interpreted the Thematic control analysis.

Irrespective of the tools used, the TCA provides common themes by identifying the patterns from the data collected. The researcher analyses and principates the details from selected list of common themes to give credentials to the participants of view across various interviewed. The coding by the researchers make very reasonable attempt to directly capture the view of the respondent. While coding and labelling by the researchers have some flexibility in terms of "Interpretation". it is bare minimum so as to not to deviate from the input received.

Fig 1 : Thematic content analysis construct

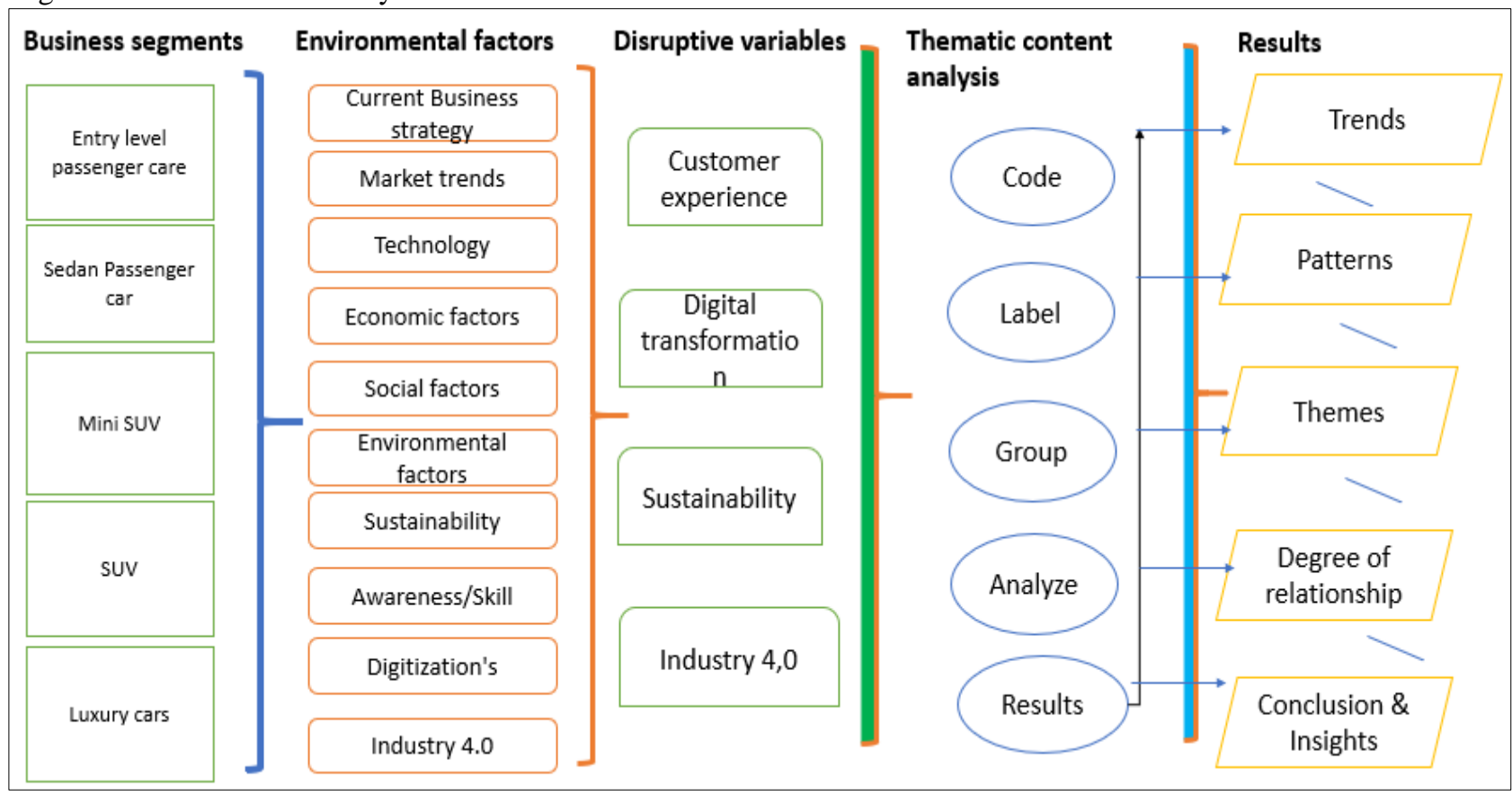

Spearman Rank Coefficient of correlation.

The Spearman's rank coefficient of correlation is a nonparametric measure of rank correlation (statistical dependence of ranking between two variables). 
For the calculation and significance testing of the ranking variable, it requires the following data assumption to hold true:

- Interval or ratio level

- Linearly related

- Bivariant distributed

If your data doesn't meet the above assumptions, then you would need Spearman's Coefficient. It is necessary to know what monotonic function is to understand Spearman correlation coefficient. A monotonic function is one that either never decreases or never increases as it is an independent variable increase. A monotonic function can be explained using the image below:

Figure 2: Monotonic Function

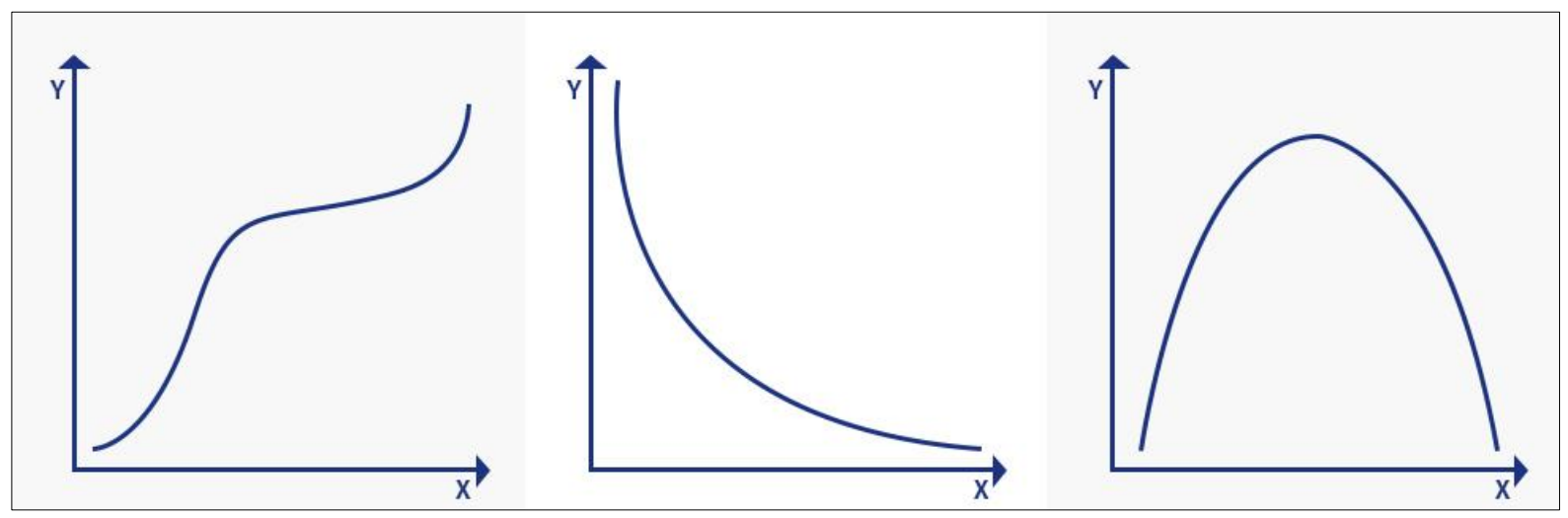

The image explains three concepts in monotonic function:

1. Monotonically increasing: When the ' $x$ ' variable increases and the ' $y$ ' variable never decreases.

2. Monotonically decreasing: When the ' $x$ ' variable increases but the ' $y$ ' variable never increases

3. Not monotonic: When the ' $x$ ' variable increases and the ' $y$ ' variable sometimes increases and sometimes decreases.

Monotonic relation is less restrictive when compared to a linear relationship that is used in Pearson's coefficient. Although monotonicity is not the ultimate requirement for Spearman correlation coefficient, it will not be meaningful to pursue Spearman's correlation without actually determining the strength and direction of a monotonic relationship if it was already known that the relationship between the variable is non-monotonic.

Spearman correlation coefficient: Formula

$$
r_{R}=1-\frac{6 \Sigma_{i} d_{i}{ }^{2}}{n\left(n^{2}-1\right)}
$$

$n=$ number of data points of the two variables

$d i=$ difference in ranks of the "ith" element

The Spearman Coefficient, $\rho$, can take a value between +1 to -1 where,

- A $\rho$ value of +1 means a perfect association of rank 
- A $\rho$ value of 0 means no association of ranks

- A $\rho$ value of -1 means a perfect negative association between rank

\section{Literature review :}

Vinit Parida ,David Sjödin \& Wiebke Reim (2019) in their study tried to come out with a framework for communicating and setting the direction for digitization ,Business models and sustainability. The article points out that the amount of productivity gains and savings using digital technology is significant and at the same time it is contributing to Sustainability by conserving the resources using the digital technology stride.

Carmen Isensee et tal (2020) in their reasrch could found ten links among business culture ,Sustainability and digitization. They have contributed a new concept of Green digitalization tools emphasizing the importance of digitization in sustainability adoption in Mid and SME companies.

Federica Ricci et tal (2020) in their study of Italian companies found that those companies which have good reputation for corporate sustainability is likely to get good valuation at marketplace if they showcase their digitization and sustainability initiave.

R. R. Sharma\& S. Mukherji (2015) in their article points out consumer, investors ; government and other stakeholders are influencing the adoption of green corporate compliance as well as accountability from the management. Changes in climate patterns ,rising energy consumption and prices are forcing government to enact laws in protecting the environment and as such change management and involvement of people as well as top management vision and leadership has become important for making sustainability in business a success. The article mentions innovations done in the oil drilling processes both physical as well as software related during this journey of aim of becoming carbon neutral.

Marlen Gabriele Arnold \$ Anne Fischer (2019) in their research article do agree that in current years the duo of digitization and sustainability has emerged as one of the key initiave. However, they also caution that there are both opportunities and threats connected with this approach. They found comprehensive analysis of strength ,opportunities, weakness and threats is not clearly available. Only positive side of digitization and sustainability is studies but there is scope to complete the entire four quadrants in a quest to understand the overall picture. There attempt to show two examples of digitization and sustainability going hand and hands shows both a progressive pattern as well as some form of tensions in certain areas.

Yasanur Kayikci,(2018) in his research article has emphasized that digitization in the supply chain not only brings benefits of productivity, agility ,transparency and speed but also the sustainability impact of digitization on supply chain or logistics. He has highlighted that the digitization has helped in reduction of CO2 emission, air and noise pollution, less fuel consumption, less land for transportation as well as social factors of sustainability got benefited through lesser impact of health hazards ,safety on the road ,fuel efficient vehicles ;Labour pattern changes and types of work.

Nada R. Sanders et tal (2019) in their reasrch article stress that entire logistics chain or supply chain have a very high impact on sustainability as it can make the company's entire logistics chain green or sustainable. They also mention that digitization has come handy to achieve this "Green" part of logistics chain for companies. They cite examples of various digital technologies including digital applications , Process automation ,AI ,Blockchain and big data as some of the digital technologies which are helping to make the business supply chain a sustainable and greener one.

Morteza Ghobakhloo (2020) in his research paper tried to construct structural model which could interpret the contextual relationship between industry 4.0 sustainability aspects. The study found a very significant relationship exists among various sustainability elements of industry 4.0 adoption. He has pointed out that industry 4.0 is defiantly contributing to sustainability by outcomes such as energy efficiency, emission reduction and social welfare and social improvements.

Middleton, K. (2005) shares his experience which is not an industry one but related to the institutions like libraries , reference archives ,Heritage material which was carried out in USA during 2005. The vast amount of physical papers was converted into digital one using scanning, digital metadata, various digital formats and software applications. This has helped to create a digital ,paperless knowledge base which was easy to use ,search was better, organization was easy. The study points out that this was a ,type of sustainability initiative as it has reduced the efforts ,resources, easy access to learners ,student and professors, long term durability ,creating a sustainable digital repository. It may seem an odd example in this paper, but I thought of including this to demonstrate the outreach of digital and sustainability connection. 
Müller, J.M.; Kiel, D.\& Voigt, K.(2018) in their study pointed out that climate/environment and social benevolence are contributing positively to the drive for adopting the new initiave of industry 4.0.However study also pointed out that this context changes with the industry and the viability and future also changes due to various hurdles in strategizing and implementing these initiatives. The article clearly points to the advantages which industry 4.0 can bring in sustainability area for the business which crosses economical benefits and enters ecology ,social and environmental domain.

Adi Kuntsman \& Imogen Rattle (2019) in their article has opposed the very basic fundamental that digitization and sustainability goes hand in hand and given a new perspective. This is exactly opposite to the widely accepted idea of digitalization helping sustainable operations. They call for a more pragmatic and innovative shift in sustainability study in the context of digitization. The digitization according to their study also results in substantial environmental damage to produce the digital devices, e-waste generation and use of increasing electricity. This inbuilt carbon footprint of digital needs to be considered while assessing the role of digitization in sustainability. According to me this is a fair assumption and the total carbon footprint also needs to include these components while arriving at net carbon footprint under an initiative.

Ang Liu ,Qinghai Zhu and setfan seuring (2020) in a special issue on new technology and implication of the same on sustainability in business, factory and supply chain found that the new technologies are playing important role in business as well as having a god impact on sustainability. They also found that the new digital technology research is often limited to one or two technology and their effect on sustainability of the business. They have suggested a comprehensive approach wherein all the related new digital technologies are evaluated with respect it impacts and correlation with sustainability in manufacturing and logistics. They also pinpointed that the approach should consider all the three tenants of sustainability environmental, social and financials and a need to balance all these three. Here they are also hinting at weighing Pros and cons as well as ROI (Rate of return).The editors of this articles also found that many researchers use different conceptual model to come out with valuable finding. The suggestion is to have a framework which can accommodate multiple technologies related to manufacturing .logistics, SCM and sales and apply it for a more comprehensive study where generalizations can become much simpler. The authors call for new models of research including simulations and game theory for realistic and pragmatic studies in these areas/

Stefan Seidel, Jan Recker and Jan vom Brocke (2013) in their article shared experience of a software solutions who has helped customer to implement business processes and practices which were sustainable in nature. The solution provided took care of conservation aspects of the sustainability in the day today operations in designing and implementing the system. Based on this the authors developed a structured framework while using information or digital systems which can help companies to adopt sustainable practices in most of their operations. The suggested framework included awareness and understanding of the current and incoming environmental requirements, developing ecofriendly and employee friendly standard practices or operating processes , Conceptualize, design and implement any digital information systems on the basis of above two requirements and last point was regarding successful execution of these software's to adopt sustainability

Parida V, Sjödin D \& Reim W.(2019) in their article acknowledge that any digital initiative execution is a challenging one and requires commitment which is ongoing and extend to continuous improvement even after implementation. The authors point out that sustainable industry is one of the objective or goal in this long journey wherein success depends on careful planning and aiming on economic ,social and sustainable benefits over a period. The digitization helps in automation; elimination of error prone tasks, increases efficiency, reduces waste and conserve resources leading to gains in quality and optimum usage of resources, thus increasing the sustainability of operations. Author suggest that sustainability should be addressed from product design to end of product Lifecyle taking care of health and safety of all the stakeholders

Opazo-Basáez M, Vendrell-Herrero F, Justina .(2018). Their article emphasize that automobile is one of the primary industries which casts critical impact on environment and as such digitization and sustainability agenda has been on radar of automotive companies for a long time. The authors points out that alogwith servitization ,automotive companies are widely adopting green practices using digital platforms and digital software's to monitor and control the sustainable projects or programs which helps in reduction in waste,emission ,energy conservation, water management and health and safety at workplace.

Review of selected literature on Digitization and sustainability clearly establishes a significant correlation between these two. Considering the importance of conservations of resources, stringent government regulation, consumer pressure ,brand image and to have competitive edge, more and more companies are adopting twin strategy of digitization and sustainability. 
Study Of Role Of Digitization In Sustainable Business In Auto Industry In India Using Thematic Content Analysis, Spearman Analysis And Review Of Literature.

\section{Analysis of Open interviews Data}

The 40 unstructured open interviews of Automotive business leaders consisted of following questions and labels to codify the response.

Table 2: List of Some of the main unstructured questions

\begin{tabular}{|c|c|c|}
\hline $\begin{array}{l}\mathrm{S} \\
\mathrm{N}\end{array}$ & Area & Unstructured Questions \\
\hline 1 & $\begin{array}{l}\text { Current Business } \\
\text { Strategy }\end{array}$ & Which are the main elements of your current Business strategy \\
\hline 2 & Market trends & Which are the 2-3 technology trends you are working on \\
\hline 3 & Technology & which are the top 3-4 areas in which your company is heavily investing \\
\hline 4 & Economic Factors & How new digitalization and innovations helping you to keep the affordability \\
\hline 5 & Social factors & Do your company have CSR policy and initiave including yearly reporting \\
\hline 6 & $\begin{array}{l}\text { Environmental } \\
\text { factor }\end{array}$ & $\begin{array}{l}\text { How your company is dealing with low emission norms and other environmental } \\
\text { regulations? }\end{array}$ \\
\hline 7 & Sustainability & $\begin{array}{l}\text { Are there any sustainability initiave going on currently with the availability of } \\
\text { high digitization? }\end{array}$ \\
\hline 8 & Awareness & $\begin{array}{l}\text { Are you aware of the UN sustainability goals ? Can you elaborate } 1 \text { or } 2 \text { of these } \\
\text { sustainability goals? }\end{array}$ \\
\hline 9 & Digitization & $\begin{array}{l}\text { Digitization and sustainability generally result in conservation of resources in } \\
\text { which areas? }\end{array}$ \\
\hline 10 & Industry 4.0 & How your company is doing with respect to industry 4.0 and IOT \\
\hline
\end{tabular}

The Responses during the random open interviews were labelled under following categories :

Table 3 : Labelling schema during interviews

\begin{tabular}{|l|l|l|l|l|l|l|l|l|l|l|l|l|}
\hline A & B & C & D & E & F & G & H & I & K & L & M & N \\
\hline $\begin{array}{l}\text { Custo } \\
\text { mer } \\
\text { centri } \\
\text { city }\end{array}$ & $\begin{array}{l}\text { New } \\
\text { produc } \\
\text { t } \\
\text { innova } \\
\text { tion }\end{array}$ & $\begin{array}{l}\text { Digit } \\
\text { al } \\
\text { busin } \\
\text { ess }\end{array}$ & $\begin{array}{l}\text { Sustaina } \\
\text { bility }\end{array}$ & $\begin{array}{l}\text { Indu } \\
\text { stry } \\
4.0\end{array}$ & $\begin{array}{l}\text { Conne } \\
\text { cted } \\
\text { Vehicl } \\
\text { e }\end{array}$ & $\begin{array}{l}\text { Saf } \\
\text { ety }\end{array}$ & $\begin{array}{l}\text { SC } \\
\text { M }\end{array}$ & $\begin{array}{l}\text { Qual } \\
\text { ity }\end{array}$ & $\begin{array}{l}\text { Hig } \\
\text { h } \\
\text { qual } \\
\text { ity } \\
\text { serv } \\
\text { ice }\end{array}$ & $\begin{array}{l}\text { Purcha } \\
\text { sing }\end{array}$ & $\begin{array}{l}\text { high } \\
\text { level } \\
\text { understa } \\
\text { nding }\end{array}$ & $\begin{array}{l}\text { Not } \\
\text { aw } \\
\text { are }\end{array}$ \\
\hline & & & & & & & & & & & & \\
\hline & & & & & & & & & & & & \\
\hline & & & & & & & & & & & & \\
\hline
\end{tabular}

The Responses from 40 random auto leaders were analyzed using labelling

Table 4: Labelling of the interview responses.

\begin{tabular}{|c|c|c|c|c|c|c|c|c|c|c|}
\hline $\begin{array}{l}\text { Responden } \\
\mathrm{t}\end{array}$ & $\mathrm{Q} 1$ & $\mathrm{Q} 2$ & Q3 & Q4 & $\begin{array}{l}\mathrm{Q} \\
5 \\
\end{array}$ & Q6 & Q7 & $\begin{array}{l}\mathrm{Q} \\
8 \\
\end{array}$ & Q9 & $\begin{array}{l}\text { Q1 } \\
0\end{array}$ \\
\hline 1 & $\mathrm{~B}, \mathrm{C}$ & C,D & C;H.L & C.D & $\mathrm{D}$ & $\mathrm{C}, \mathrm{D}, \mathrm{I}$ & D, H,L & M & $\begin{array}{l}\text { C.D,H. } \\
\mathrm{L}\end{array}$ & $\mathrm{M}$ \\
\hline 2 & C.D,F & $\mathrm{H} ; \mathrm{L}, \mathrm{D}$ & $\mathrm{C}, \mathrm{L}, \mathrm{E}$ & $\begin{array}{l}\mathrm{C}, \mathrm{D}, \mathrm{H}, \\
\mathrm{L}\end{array}$ & $\mathrm{D}$ & C,D,E & H.L,D & D & H,K.L & M \\
\hline 3 & A.E,F & $\mathrm{C}, \mathrm{D}, \mathrm{H}$ & $\begin{array}{l}\mathrm{C}, \mathrm{D}, \mathrm{H}, \\
\mathrm{L}\end{array}$ & H;L.C & $\mathrm{D}$ & & C,D,E & M & $\mathrm{B}, \mathrm{H}, \mathrm{L}$ & M \\
\hline 4 & $\begin{array}{l}\text { A,C,D, } \\
\text { E }\end{array}$ & $\begin{array}{l}\mathrm{C}, \mathrm{D}, \mathrm{E}, \\
\mathrm{L}\end{array}$ & $\mathrm{H}, \mathrm{C}, \mathrm{I}$ & $\mathrm{H}, \mathrm{I}, \mathrm{C}, \mathrm{D}$ & $\mathrm{D}$ & $\mathrm{C}, \mathrm{D}, \mathrm{H}, \mathrm{L}$ & $\begin{array}{l}\text { C.D.E,F, } \\
\mathrm{H}\end{array}$ & M & H,I.L & $\mathrm{M}$ \\
\hline 5 & $\begin{array}{l}\mathrm{A}, \mathrm{B}, \mathrm{C}, \\
\mathrm{D}\end{array}$ & $\begin{array}{l}\text { C,D,L. } \\
\mathrm{F}\end{array}$ & $\mathrm{C}, \mathrm{D}, \mathrm{F}$ & $\mathrm{H} ; \mathrm{L}, \mathrm{I}, \mathrm{C}$ & $\mathrm{D}$ & $\begin{array}{l}\text { H,I,C,L, } \\
\mathrm{E}\end{array}$ & $\mathrm{C}, \mathrm{D}, \mathrm{H}, \mathrm{I} ; \mathrm{L}$ & D & H.I.L & $\mathrm{M}$ \\
\hline
\end{tabular}




\begin{tabular}{|c|c|c|c|c|c|c|c|c|c|c|}
\hline 6 & C.D,F & $\mathrm{H} ; \mathrm{L}, \mathrm{D}$ & $\mathrm{C}, \mathrm{L}, \mathrm{E}$ & $\begin{array}{l}\mathrm{C}, \mathrm{D}, \mathrm{H}, \\
\mathrm{L}\end{array}$ & $\mathrm{D}$ & C,D,E & H.L,D & D & H,K.L & $\mathrm{M}$ \\
\hline 7 & C.D.E & $\begin{array}{l}\text { C,D,E, } \\
\text { F }\end{array}$ & $\begin{array}{l}\text { H.L.K, } \\
\text { E }\end{array}$ & H,I.L & $\mathrm{D}$ & $\mathrm{C}, \mathrm{D}, \mathrm{E}, \mathrm{F}$ & H,I.L & $\mathrm{D}$ & H.I.L.K & $\mathrm{M}$ \\
\hline 8 & $\mathrm{~B}, \mathrm{C}$ & C,D & C;H.L & C.D & $\mathrm{D}$ & $\mathrm{C}, \mathrm{D}, \mathrm{I}$ & C.D.H.L & M & $\begin{array}{l}\text { C.D,H. } \\
\text { L }\end{array}$ & M \\
\hline 9 & A.E,F & $\mathrm{C}, \mathrm{D}, \mathrm{H}$ & $\begin{array}{l}\text { C,D,H, } \\
\mathrm{L}\end{array}$ & H;L.C & $\mathrm{D}$ & $\mathrm{C}, \mathrm{D}, \mathrm{H}, \mathrm{L}$ & C,D,E & M & $\mathrm{B}, \mathrm{H}, \mathrm{L}$ & $\mathrm{M}$ \\
\hline 10 & C.D,F & $\mathrm{H} ; \mathrm{L}, \mathrm{D}$ & C,L,E & $\begin{array}{l}\mathrm{C}, \mathrm{D}, \mathrm{H}, \\
\mathrm{L}\end{array}$ & $\mathrm{D}$ & C,D,E & H.L,D & $\mathrm{D}$ & H,K.L & M \\
\hline 11 & $\begin{array}{l}\mathrm{A}, \mathrm{C}, \mathrm{D}, \\
\mathrm{E}\end{array}$ & $\begin{array}{l}\text { C,D,E, } \\
\mathrm{L}\end{array}$ & $\mathrm{H}, \mathrm{C}, \mathrm{l}$ & $\mathrm{h} ; \mathrm{l}, \mathrm{c}, \mathrm{d}$ & $\mathrm{D}$ & $\mathrm{C}, \mathrm{D}, \mathrm{H}, \mathrm{L}$ & $\begin{array}{l}\text { C.D.E,F, } \\
\text { H }\end{array}$ & M & H,I.L & $\mathrm{M}$ \\
\hline 12 & A.E,F & $\mathrm{C}, \mathrm{D}, \mathrm{H}$ & $\begin{array}{l}\text { C,D,H, } \\
\text { L }\end{array}$ & H;L.C & $\mathrm{D}$ & $\mathrm{C}, \mathrm{D}, \mathrm{H}, \mathrm{L}$ & $\mathrm{C}, \mathrm{D}, \mathrm{E}$ & M & $\mathrm{B}, \mathrm{H}, \mathrm{L}$ & M \\
\hline 13 & $\mathrm{~B}, \mathrm{C}$ & C,D & C;H.L & C.D & $\mathrm{D}$ & $\mathrm{C}, \mathrm{D}, \mathrm{I}$ & C.D.H.L & M & $\begin{array}{l}\text { C.D,H. } \\
\mathrm{L}\end{array}$ & $\mathrm{M}$ \\
\hline 14 & A.E,F & $\mathrm{C}, \mathrm{D}, \mathrm{H}$ & $\begin{array}{l}\mathrm{C}, \mathrm{D}, \mathrm{H}, \\
\mathrm{L}\end{array}$ & H;L.C & $\mathrm{D}$ & $\mathrm{C}, \mathrm{D}, \mathrm{H}, \mathrm{L}$ & C,D,E & M & $\mathrm{B}, \mathrm{H}, \mathrm{L}$ & M \\
\hline 15 & C.D,F & $\mathrm{H} ; \mathrm{L}, \mathrm{D}$ & $\mathrm{C}, \mathrm{L}, \mathrm{E}$ & $\begin{array}{l}\mathrm{C}, \mathrm{D}, \mathrm{H}, \\
\mathrm{L}\end{array}$ & $\mathrm{D}$ & C,D,E & H.L,D & $\mathrm{D}$ & $\mathrm{H}, \mathrm{K} . \mathrm{L}$ & M \\
\hline 16 & $\begin{array}{l}\text { A,C,D, } \\
\text { E }\end{array}$ & $\begin{array}{l}\text { C,D,E, } \\
\text { L }\end{array}$ & $\mathrm{H}, \mathrm{C}, \mathrm{l}$ & $\mathrm{h} ; \mathrm{l}, \mathrm{c}, \mathrm{d}$ & $\mathrm{D}$ & $\mathrm{C}, \mathrm{D}, \mathrm{H}, \mathrm{L}$ & $\begin{array}{l}\text { C.D.E,F, } \\
\text { H }\end{array}$ & M & H,I.L & M \\
\hline 17 & $\mathrm{~B}, \mathrm{C}$ & C,D & C;H.L & C.D & $\mathrm{D}$ & $\mathrm{C}, \mathrm{D}, \mathrm{I}$ & C.D.H.L & M & $\begin{array}{l}\text { C.D,H. } \\
\text { L }\end{array}$ & $\mathrm{M}$ \\
\hline 18 & $\begin{array}{l}\text { A,C,D, } \\
\text { E }\end{array}$ & $\begin{array}{l}\mathrm{C}, \mathrm{D}, \mathrm{E}, \\
\mathrm{L}\end{array}$ & $\mathrm{H}, \mathrm{C}, \mathrm{I}$ & $\mathrm{h} ; \mathrm{l}, \mathrm{c}, \mathrm{d}$ & $\mathrm{D}$ & $\mathrm{C}, \mathrm{D}, \mathrm{H}, \mathrm{L}$ & $\begin{array}{l}\text { C.D.E,F, } \\
\mathrm{H}\end{array}$ & M & H,I.L & M \\
\hline 19 & C.D,F & $\mathrm{H} ; \mathrm{L}, \mathrm{D}$ & $\mathrm{C}, \mathrm{L}, \mathrm{E}$ & $\begin{array}{l}\mathrm{C}, \mathrm{D}, \mathrm{H}, \\
\mathrm{L}\end{array}$ & $\mathrm{D}$ & $\mathrm{C}, \mathrm{D}, \mathrm{E}$ & H.L,D & D & H,K.L & M \\
\hline 20 & $\mathrm{~B}, \mathrm{C}$ & C,D & C;H.L & C.D & $\mathrm{D}$ & $\mathrm{C}, \mathrm{D}, \mathrm{I}$ & C.D.H.L & M & $\begin{array}{l}\text { C.D,H. } \\
\text { L }\end{array}$ & M \\
\hline 21 & C.D,F & $\mathrm{H} ; \mathrm{L}, \mathrm{D}$ & $\mathrm{C}, \mathrm{L}, \mathrm{E}$ & $\begin{array}{l}\text { C,D,H, } \\
\text { L }\end{array}$ & $\mathrm{D}$ & $\mathrm{C}, \mathrm{D}, \mathrm{E}$ & H.L,D & $\mathrm{D}$ & H,K.L & $\mathrm{M}$ \\
\hline 22 & C.D.E & $\begin{array}{l}\text { C,D,E, } \\
F\end{array}$ & $\begin{array}{l}\text { H.L.K, } \\
\text { E }\end{array}$ & H,I.L & D & $\mathrm{C}, \mathrm{D}, \mathrm{E}, \mathrm{F}$ & H,I.L & D & H.I.L.K & $\mathrm{M}$ \\
\hline 23 & $\mathrm{~B}, \mathrm{C}$ & $\mathrm{C}, \mathrm{D}$ & C;H.L & C.D & $\mathrm{D}$ & $\mathrm{C}, \mathrm{D}, \mathrm{I}$ & C.D.H.L & $\mathrm{M}$ & $\begin{array}{l}\text { C.D,H. } \\
\mathrm{L}\end{array}$ & $\mathrm{M}$ \\
\hline 24 & C.D,F & H;L,D & $\mathrm{C}, \mathrm{L}, \mathrm{E}$ & $\begin{array}{l}\mathrm{C}, \mathrm{D}, \mathrm{H}, \\
\mathrm{L}\end{array}$ & $\mathrm{D}$ & $\mathrm{C}, \mathrm{D}, \mathrm{E}$ & H.L,D & $\mathrm{D}$ & H,K.L & $\mathrm{M}$ \\
\hline 25 & C.D.E & $\begin{array}{l}\mathrm{C}, \mathrm{D}, \mathrm{E}, \\
\mathrm{F}\end{array}$ & $\begin{array}{l}\text { H.L.K, } \\
\text { E }\end{array}$ & H,I.L & $\mathrm{D}$ & $\mathrm{C}, \mathrm{D}, \mathrm{E}, \mathrm{F}$ & H,I.L & $\mathrm{D}$ & H.I.L.K & $\mathrm{M}$ \\
\hline 26 & $\mathrm{~B}, \mathrm{C}$ & C,D & C;H.L & C.D & $\mathrm{D}$ & $\mathrm{C}, \mathrm{D}, \mathrm{I}$ & C.D.H.L & M & $\begin{array}{l}\text { C.D,H. } \\
\mathrm{L}\end{array}$ & $\mathrm{M}$ \\
\hline 27 & C.D,F & $\mathrm{H} ; \mathrm{L}, \mathrm{D}$ & $\mathrm{C}, \mathrm{L}, \mathrm{E}$ & $\begin{array}{l}\text { C,D,H, } \\
\text { L }\end{array}$ & $\mathrm{D}$ & $\mathrm{C}, \mathrm{D}, \mathrm{E}$ & H.L,D & $\mathrm{D}$ & H,K.L & M \\
\hline 28 & C.D,F & $\mathrm{H} ; \mathrm{L}, \mathrm{D}$ & C,L,E & $\begin{array}{l}\mathrm{C}, \mathrm{D}, \mathrm{H}, \\
\mathrm{L}\end{array}$ & $\mathrm{D}$ & $\mathrm{C}, \mathrm{D}, \mathrm{E}$ & H.L,D & $\mathrm{D}$ & H,K.L & M \\
\hline 29 & A.E,F & $\mathrm{C}, \mathrm{D}, \mathrm{H}$ & $\begin{array}{l}\mathrm{C}, \mathrm{D}, \mathrm{H}, \\
\mathrm{L}\end{array}$ & H;L.C & $\mathrm{D}$ & $\mathrm{C}, \mathrm{D}, \mathrm{H}, \mathrm{L}$ & $\mathrm{C}, \mathrm{D}, \mathrm{E}$ & M & $\mathrm{B}, \mathrm{H}, \mathrm{L}$ & $\mathrm{M}$ \\
\hline 30 & $\mathrm{~B}, \mathrm{C}$ & $\mathrm{C}, \mathrm{D}$ & C;H.L & C.D & $\mathrm{D}$ & $\mathrm{C}, \mathrm{D}, \mathrm{I}$ & C.D.H.L & $\mathrm{M}$ & $\begin{array}{l}\text { C.D,H. } \\
\text { L }\end{array}$ & $\mathrm{M}$ \\
\hline 31 & C.D,F & $\mathrm{H} ; \mathrm{L}, \mathrm{D}$ & $\mathrm{C}, \mathrm{L}, \mathrm{E}$ & $\begin{array}{l}\text { C,D,H, } \\
\text { L }\end{array}$ & $\mathrm{D}$ & C,D,E & H.L,D & $\mathrm{D}$ & H,K.L & M \\
\hline 32 & C.D.E & $\begin{array}{l}\mathrm{C}, \mathrm{D}, \mathrm{E}, \\
\mathrm{F}\end{array}$ & $\begin{array}{l}\text { H.L.K, } \\
\text { E }\end{array}$ & H,I.L & $\mathrm{D}$ & $\mathrm{C}, \mathrm{D}, \mathrm{E}, \mathrm{F}$ & H,I.L & $\mathrm{D}$ & H.I.L.K & M \\
\hline 33 & $\mathrm{~B}, \mathrm{C}$ & $\mathrm{C}, \mathrm{D}$ & C;H.L & C.D & $\mathrm{D}$ & $\mathrm{C}, \mathrm{D}, \mathrm{I}$ & C.D.H.L & M & $\begin{array}{l}\text { C.D,H. } \\
\text { L }\end{array}$ & $\mathrm{M}$ \\
\hline 34 & C.D,F & $\mathrm{H} ; \mathrm{L}, \mathrm{D}$ & $\mathrm{C}, \mathrm{L}, \mathrm{E}$ & $\begin{array}{l}\mathrm{C}, \mathrm{D}, \mathrm{H}, \\
\mathrm{L}\end{array}$ & $\mathrm{D}$ & C,D,E & H.L,D & $\mathrm{D}$ & H,K.L & $\mathrm{M}$ \\
\hline
\end{tabular}


Study Of Role Of Digitization In Sustainable Business In Auto Industry In India Using Thematic Content Analysis, Spearman Analysis And Review Of Literature.

\begin{tabular}{|c|c|c|c|c|c|c|c|c|c|c|}
\hline 35 & C.D.E & $\begin{array}{l}\mathrm{C}, \mathrm{D}, \mathrm{E}, \\
\mathrm{F}\end{array}$ & $\begin{array}{l}\text { H.L.K, } \\
\text { E }\end{array}$ & H,I.L & $\mathrm{D}$ & C,D,E,F & H,I.L & D & H.I.L.K & $\mathrm{M}$ \\
\hline 36 & $\mathrm{~B}, \mathrm{C}$ & C,D & C;H.L & C.D & $\mathrm{D}$ & $\mathrm{C}, \mathrm{D}, \mathrm{I}$ & C.D.H.L & $\mathrm{M}$ & $\begin{array}{l}\text { C.D,H. } \\
\text { L }\end{array}$ & $\mathrm{M}$ \\
\hline 37 & C.D,F & $\mathrm{H} ; \mathrm{L}, \mathrm{D}$ & $\mathrm{C}, \mathrm{L}, \mathrm{E}$ & $\begin{array}{l}\mathrm{C}, \mathrm{D}, \mathrm{H}, \\
\mathrm{L}\end{array}$ & $\mathrm{D}$ & C,D,E & H.L,D & $\mathrm{D}$ & H,K.L & M \\
\hline 38 & $\mathrm{~B}, \mathrm{C}$ & C,D & C;H.L & C.D & $\mathrm{D}$ & $\mathrm{C}, \mathrm{D}, \mathrm{I}$ & C.D.H.L & M & $\begin{array}{l}\text { C.D,H. } \\
\text { L }\end{array}$ & $\mathrm{M}$ \\
\hline 39 & C.D,F & $\mathrm{H} ; \mathrm{L}, \mathrm{D}$ & $\mathrm{C}, \mathrm{L}, \mathrm{E}$ & $\begin{array}{l}\mathrm{C}, \mathrm{D}, \mathrm{H}, \\
\mathrm{L}\end{array}$ & $\mathrm{D}$ & $\mathrm{C}, \mathrm{D}, \mathrm{E}$ & H.L,D & $\mathrm{D}$ & H,K.L & $\mathrm{M}$ \\
\hline 40 & $\mathrm{~B}, \mathrm{C}$ & C,D & C;H.L & C.D & $\mathrm{D}$ & $\mathrm{C}, \mathrm{D}, \mathrm{I}$ & C.D.H.L & M & $\begin{array}{l}\text { C.D,H. } \\
\text { L }\end{array}$ & M \\
\hline
\end{tabular}

Patterns \& Themes out of the analysis.

Fig 2 : Theme/Pattern analysis of interview responses

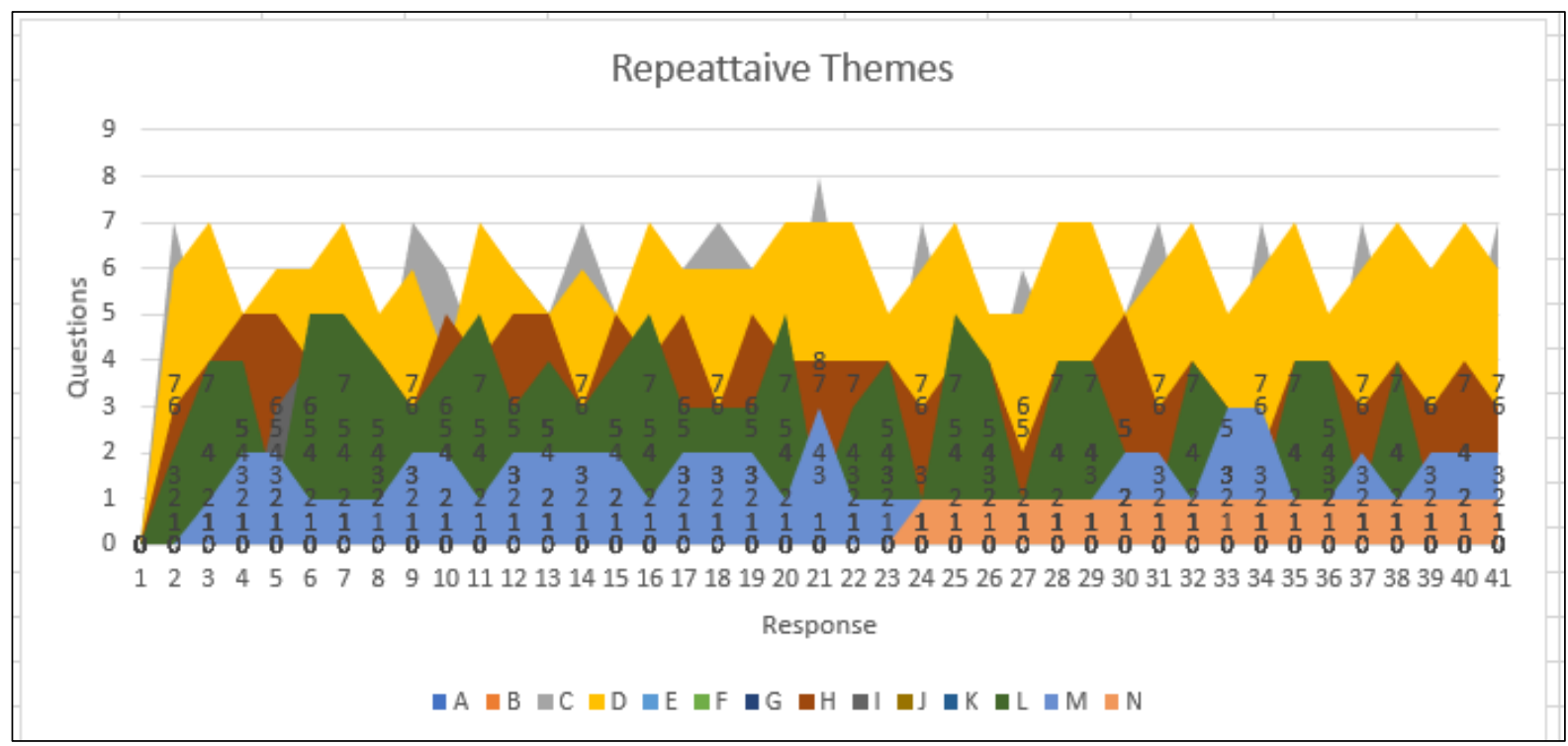

The Patterns clearly indicates following four important themes coming out of the analysis and Sustainability and digitalization are the top 2 . The review of literature also suggests a significant and positive correlation ship between sustainability and digitization.

Table 5 : Top 4 Themes/Pattern in su business in Indian Auto Industry.

\begin{tabular}{|r|r|l|}
\hline \multicolumn{1}{|l|}{ SN } & \multicolumn{2}{|c|}{ Top Theme /pattern } \\
\hline 1 & D & Sustainability \\
\hline 2 & C & Digitization \\
\hline 3 & H & SCM \\
\hline 4 & L & Purchasing \\
\hline
\end{tabular}

Combining review of literature findings as well as qualitative analysis based on 40 Automobile leaders unstructured review \& analysis clearly indicates a positive and significant relationship between sustainability and digitalization. However, this needs statistical backing. We have decided to back this using Spearman Nonparametric Co-relation coefficient. Though the thematic analysis shows the corresponding changes (Up/down) with the help of graphical and numerical representation, it is not considered enough from reasrch point to define the direction and degree of relationship between the variables under study.

Based on extensive discussions and review of literature, we have decided to go for Spearman Nonparametric correlation estimation for establishing a statistically significant relationship between

1. Digitization and sustainability

2. Industry 4.0 and sustainability 


\section{Spearman Nonparametric Co-relation Coefficient}

Spearman's correlation measures the strength and direction of monotonic association between two variables. Monotonicity is "less restrictive" than that of a linear relationship.

A monotonic relationship is not strictly an assumption of Spearman's correlation. That is, you can run a Spearman's correlation on a non-monotonic relationship to determine if there is a monotonic component to the association. However, you would normally pick a measure of association, such as Spearman's correlation, that fits the pattern of the observed data. That is, if a scatterplot shows that the relationship between your two variables looks monotonic you would run a Spearman's correlation because this will then measure the strength and direction of this monotonic relationship. On the other hand if, for example, the relationship appears linear (assessed via scatterplot) you would run a Pearson's correlation because this will measure the strength and direction of any linear relationship.

We have analyzed the interview data for Digitization initiave ,Sustainability and Industry 4.0. The paired data comparison for 40 interviews for these variables is done. First step in this was to plat the trend diagrams. The trends diagrams for the paired variables are given below:

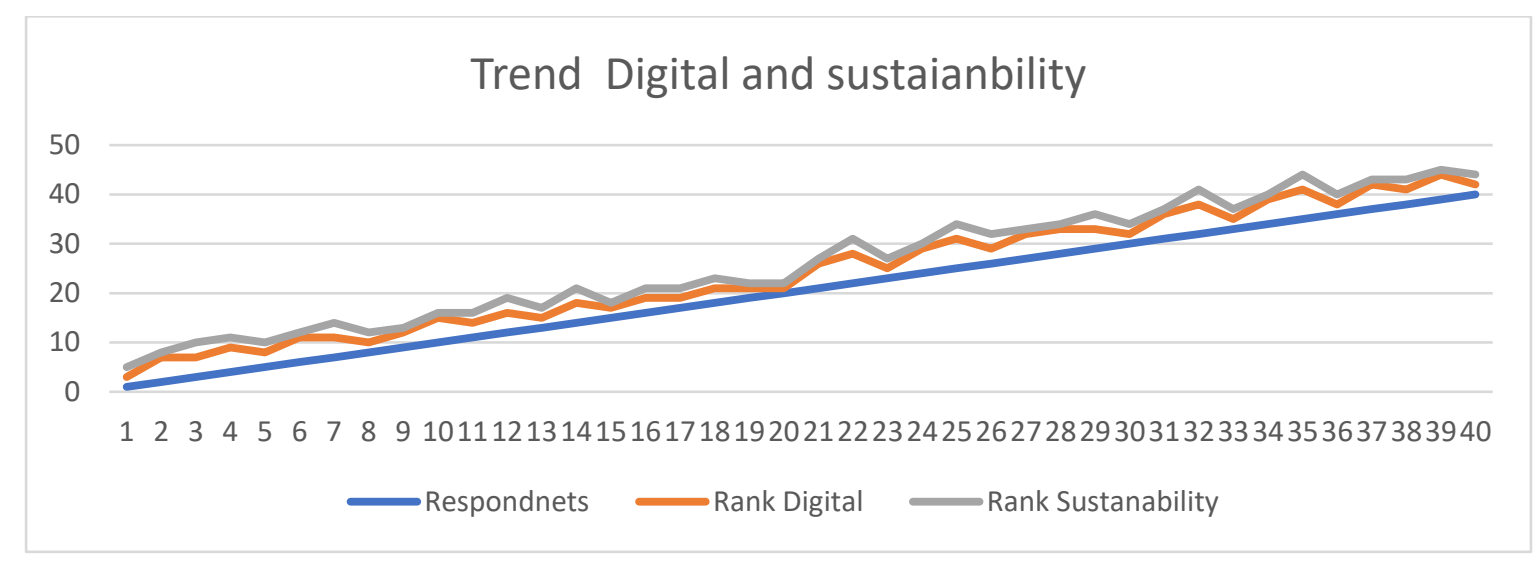

Based on the trend pattern, it was decided to use Spearman's Co-efficient rather than Pearson co-efficient for analysis as the trend diagrams shows a Monotonic and uniform patterns.

Fig 4 : Sustainability and Industry 4.0 trend

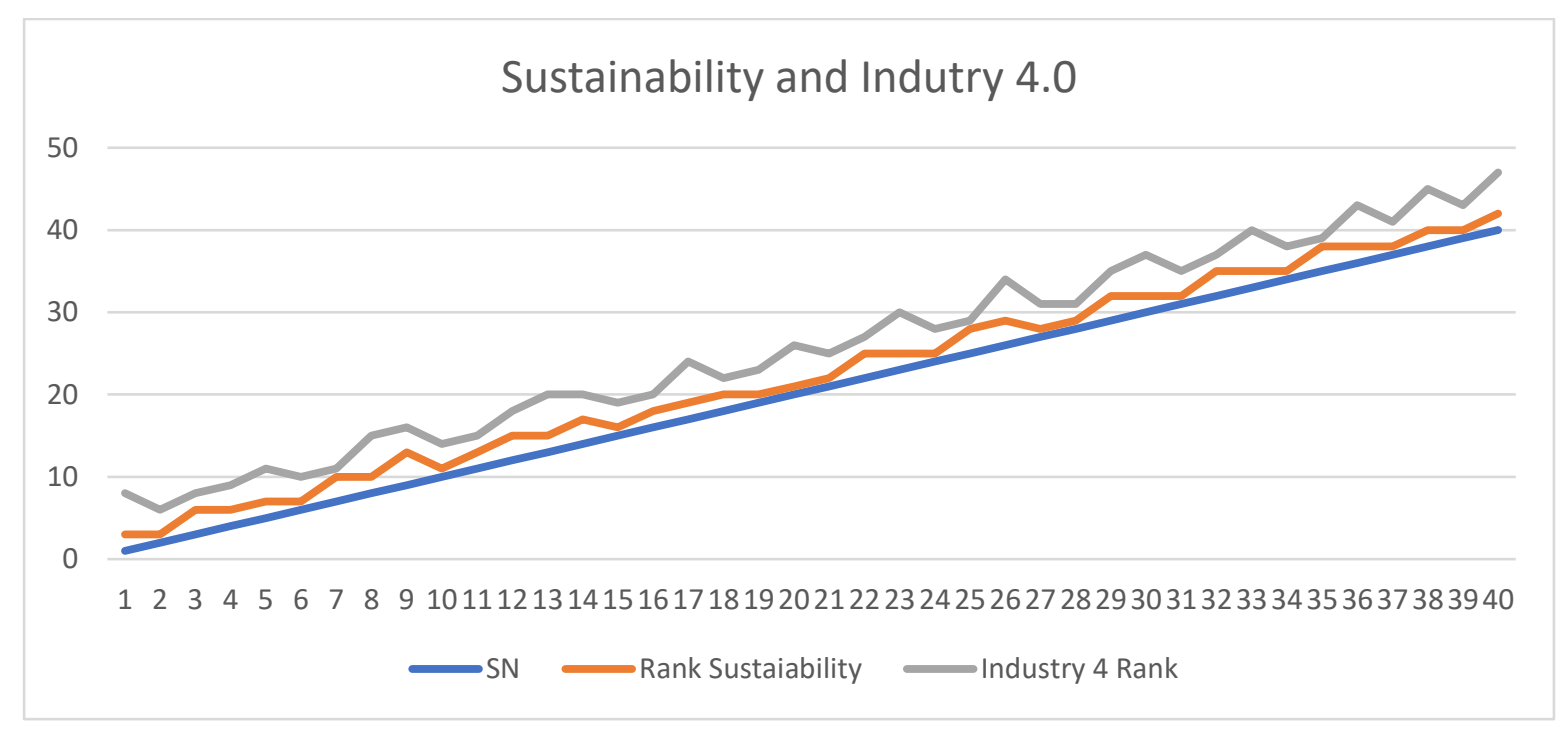

Spearman Co-relation Coefficient analysis. 
Study Of Role Of Digitization In Sustainable Business In Auto Industry In India Using Thematic Content Analysis, Spearman Analysis And Review Of Literature.

\section{Digitization and sustainability}

\begin{tabular}{|c|c|c|c|c|c|c|}
\hline $\begin{array}{l}\text { Responde } \\
\text { nt }\end{array}$ & Digital Business & $\begin{array}{l}\text { Sustainabili } \\
\text { ty }\end{array}$ & $\begin{array}{l}\text { Rank } \\
\text { Digital } \\
\end{array}$ & $\begin{array}{l}\text { Rank } \\
\text { Sustainabilit } \\
\text { y }\end{array}$ & $\begin{array}{l}\mathrm{D}=\text { Rank1 - } \\
\text { Rank2 }\end{array}$ & $\begin{array}{l}\mathrm{D} \\
\text { Square }\end{array}$ \\
\hline Q.No----> & $\mathrm{C}$ & $\mathrm{D}$ & & & & \\
\hline 1 & 7 & 6 & 2 & 2 & 0 & 0 \\
\hline 2 & 4 & 7 & 5 & 1 & 4 & 16 \\
\hline 3 & 5 & 5 & 4 & 3 & 1 & 1 \\
\hline 4 & 4 & 6 & 5 & 2 & 3 & 9 \\
\hline 5 & 6 & 6 & 3 & 2 & 1 & 1 \\
\hline 6 & 4 & 7 & 5 & 1 & 4 & 16 \\
\hline 7 & 3 & 5 & 4 & 3 & 1 & 1 \\
\hline 8 & 7 & 6 & 2 & 2 & 0 & 0 \\
\hline 9 & 6 & 4 & 3 & 1 & 2 & 4 \\
\hline 10 & 4 & 7 & 5 & 1 & 4 & 16 \\
\hline 11 & 6 & 6 & 3 & 2 & 1 & 1 \\
\hline 12 & 5 & 5 & 4 & 3 & 1 & 1 \\
\hline 13 & 7 & 6 & 2 & 2 & 0 & 0 \\
\hline 14 & 5 & 5 & 4 & 3 & 1 & 1 \\
\hline 15 & 4 & 7 & 2 & 1 & 1 & 1 \\
\hline 16 & 6 & 6 & 3 & 2 & 1 & 1 \\
\hline 17 & 7 & 6 & 2 & 2 & 0 & 0 \\
\hline 18 & 6 & 6 & 3 & 2 & 1 & 1 \\
\hline 19 & 4 & 7 & 2 & 1 & 1 & 1 \\
\hline 20 & 8 & 7 & 1 & 1 & 0 & 0 \\
\hline 21 & 4 & 7 & 5 & 1 & 4 & 16 \\
\hline 22 & 3 & 5 & 6 & 3 & 3 & 9 \\
\hline 23 & 7 & 6 & 2 & 2 & 0 & 0 \\
\hline 24 & 4 & 7 & 5 & 1 & 4 & 16 \\
\hline 25 & 3 & 5 & 6 & 3 & 3 & 9 \\
\hline 26 & 6 & 5 & 3 & 3 & 0 & 0 \\
\hline 27 & 4 & 7 & 5 & 1 & 4 & 16 \\
\hline 28 & 4 & 7 & 5 & 1 & 4 & 16 \\
\hline 29 & 5 & 5 & 4 & 3 & 1 & 1 \\
\hline 30 & 7 & 6 & 2 & 2 & 0 & 0 \\
\hline 31 & 4 & 7 & 5 & 1 & 4 & 16 \\
\hline 32 & 3 & 5 & 6 & 3 & 3 & 9 \\
\hline 33 & 7 & 6 & 2 & 2 & 0 & 0 \\
\hline 34 & 4 & 7 & 5 & 1 & 4 & 16 \\
\hline 35 & 3 & 5 & 6 & 3 & 3 & 9 \\
\hline 36 & 7 & 6 & 2 & 2 & 0 & 0 \\
\hline 37 & 4 & 7 & 5 & 1 & 4 & 16 \\
\hline 38 & 6 & 6 & 3 & 2 & 1 & 1 \\
\hline
\end{tabular}




\begin{tabular}{|r|r|r|r|r|r|r|}
39 & 4 & 7 & 5 & 1 & 4 & 16 \\
\hline 40 & 7 & 6 & 2 & 2 & 0 & 0 \\
\hline
\end{tabular}

Total

$$
\begin{aligned}
& \rho=1-\frac{6 \sum d_{i}^{2}}{n\left(n^{2}-1\right)} \\
& \mathrm{P}(40)=\quad 0.9777673
\end{aligned}
$$$$
\text { D2 } 1422
$$$$
\text { N(M2-1) }
$$$$
63960
$$

\begin{tabular}{|c|c|c|c|c|c|c|}
\hline Respondent & Sustainability & Industry 4 & Rank Sustainability & Industry 4 Rank & $\mathrm{D}$ & D square \\
\hline 1 & 6 & 0 & 2 & 5 & -3 & 9 \\
\hline 2 & 7 & 2 & 1 & 3 & -2 & 4 \\
\hline 3 & 5 & 3 & 3 & 2 & 1 & 1 \\
\hline 4 & 6 & 2 & 2 & 3 & -1 & 1 \\
\hline 5 & 6 & 1 & 2 & 4 & -2 & 4 \\
\hline 6 & 7 & 2 & 1 & 3 & -2 & 4 \\
\hline 7 & 5 & 4 & 3 & 1 & 2 & 4 \\
\hline 8 & 6 & 0 & 2 & 5 & -3 & 9 \\
\hline 9 & 4 & 2 & 4 & 3 & 1 & 1 \\
\hline 10 & 7 & 2 & 1 & 3 & -2 & 4 \\
\hline 11 & 6 & 3 & 2 & 2 & 0 & 0 \\
\hline 12 & 5 & 2 & 3 & 3 & 0 & 0 \\
\hline 13 & 6 & 0 & 2 & 5 & -3 & 9 \\
\hline 14 & 5 & 2 & 3 & 3 & 0 & 0 \\
\hline 15 & 7 & 2 & 1 & 3 & -2 & 4 \\
\hline 16 & 6 & 3 & 2 & 2 & 0 & 0 \\
\hline 17 & 6 & 0 & 2 & 5 & -3 & 9 \\
\hline 18 & 6 & 3 & 2 & 2 & 0 & 0 \\
\hline 19 & 7 & 2 & 1 & 3 & -2 & 4 \\
\hline 20 & 7 & 0 & 1 & 5 & -4 & 16 \\
\hline 21 & 7 & 2 & 1 & 3 & -2 & 4 \\
\hline 22 & 5 & 3 & 3 & 2 & 1 & 1 \\
\hline 23 & 6 & 0 & 2 & 5 & -3 & 9 \\
\hline 24 & 7 & 2 & 1 & 3 & -2 & 4 \\
\hline 25 & 5 & 4 & 3 & 1 & 2 & 4 \\
\hline 26 & 5 & 0 & 3 & 5 & -2 & 4 \\
\hline 27 & 7 & 2 & 1 & 3 & -2 & 4 \\
\hline
\end{tabular}

2. Sustainability \& Industry 4.0 
Study Of Role Of Digitization In Sustainable Business In Auto Industry In India Using Thematic Content Analysis, Spearman Analysis And Review Of Literature.

\begin{tabular}{|r|r|r|r|r|r|r|}
\hline 28 & 7 & 3 & 1 & 2 & -1 & 1 \\
\hline 29 & 5 & 2 & 3 & 3 & 0 & 0 \\
\hline 30 & 6 & 0 & 2 & 5 & -3 & 9 \\
\hline 31 & 7 & 2 & 1 & 3 & -2 & 4 \\
\hline 32 & 5 & 3 & 3 & 2 & 1 & 1 \\
\hline 33 & 6 & 0 & 2 & 5 & -3 & 9 \\
\hline 34 & 7 & 2 & 1 & 3 & -2 & 4 \\
\hline 35 & 5 & 4 & 3 & 1 & 2 & 4 \\
\hline 36 & 6 & 0 & 2 & 5 & -3 & 9 \\
\hline 37 & 7 & 2 & 1 & 3 & -2 & 4 \\
\hline 38 & 6 & 0 & 2 & 5 & -3 & 9 \\
\hline 39 & 7 & 2 & 1 & 3 & -2 & 4 \\
\hline 40 & 6 & 0 & 2 & 5 & -3 & 9 \\
\hline
\end{tabular}

\begin{tabular}{|lr|}
\hline & \\
$\mathrm{D} 2$ & 180 \\
$\mathrm{~N}$ & 40 \\
$\mathrm{~N}(\mathrm{M} 2-1)$ & 63960 \\
$\mathrm{p}$ & 0.983114447 \\
\hline
\end{tabular}

\section{The analysis here shows that the Spearman coefficient of relationship between :}

- Digitalization and sustainability: 0.97 ( Very high significant co-relationship)

- Sustainability \& Industry 4.0: 0.98 (Very high significant co-relationship)

Barring the scoring bias, in an open unstructured interview as given below ..

- Confirmation bias. Occurs when the person performing the data analysis wants to prove a predetermined assumption.

- Selection bias. This occurs when data is selected subjectively.

- Outliers. An outlier is an extreme data value.

- Overfitting an underfitting response

- Confounding variables.

Even if we consider the bias to the tune of 20 t0 30\%, due to personal ,professional and company influence , the adjusted Coefficient of correlation will be in the range of :

- Digitalization and sustainability: 0.97 ( Very high significant co-relationship)

$$
20 \% \quad 77 \quad 68
$$

$30 \%$

- Sustainability \& Industry 4.0: 0.98 (Very high significant co-relationship)

$\begin{array}{ll}20 \% & 78 \\ 30 \% & 69\end{array}$

Even removing the traditional bias as per review of literature, there is significant positive statistical positive correlation between,

- Digitalization and sustainability

- Sustainability \& Industry 4.0: 


\section{Findings and observations from interviews with Business leaders}

The interviews and discussions with 40 business leaders' overs a span of 2 years bought about significant insights with respect to digitization and sustainability initiatives in Automobile industry in India.

- There is significant positive relationship between digitization ans sustainability (68 to 77\%) after removing the biases in interview reposes.

- $\quad$ There is significant positive relationship between Industry 4.0n and sustainability (78 to $69 \%$ ) after removing the biases in interview reposes.

- Almost all those interviewed agreed that sustainability has become one of the strategic points alogwith business growth in last 10 years.

- Almost $100 \%$ of the companies have CSR (Corporate social responsibility) initiatives in one or the other from and they are getting reported in company's annual report.

- Almost $90 \%$ of the interviewed informed that digitization coupled with sustainability goals are going on in their organization and they are in various stages of implementation.

- Shop floor automation ,Supply chain \& Green purchasing, these 3 areas are found to be under implementation in at least $60 \%$ of the respondent. Balance respondent did not elaborate much on these but nodded it is on their agenda.

- Many leaders still found connecting digitization and sustainability clearly as the software and physical actions part of sustainability often confuse them.

- Most of the leaders are aware of different standards for sustainability, however they could not elaborate much on the details.

- Some of the leaders suggested, that this is focus area but requires expert guidance and lot of investment. ( which is not true if we weigh the Pros and cons).

- Business leaders were found to be more aware of benefits due to sustainability than the IT leaders interviewed.

- $80 \%$ of the leaders say that industry 4.0 and IOT are still far away as currently only proof of concept or some sample projects are going on.

\section{Limitation of the study :}

- The answers during the interview sometimes were found to be influenced by their position, company's image and sharing of confidential information.

- Sample size of the interview was 40 but it was a random sample and considering that there are only 10 major OEM manufacturers $n$ India, we thought it to be representative.

- No detail elaboration on sustainability initiave was shared. It was brief answers on a high level.(Probability not to divulge details due to confidentiality)

\section{Future Scope :}

- A full-blown study on digitization and sustainability in various industries including Automobile can help further to understand the correlation, impact and Return on investment in detail. Full blown study here means multiple technology and entire product value chain study and not an isolated part to get a clear picture.

- Sustainability benchmarking for the current state of the business is still an issue and there are no industry specific frameworks available to calculate the current state and plan for the further steps in digitization and sustainability.

- Though there are certain measures like CO2 emission ,Carbon footprint, waste generated amount available , a detailed scorecard covering design to end of lifecycle needs to be put in place. Complete Key performance indicators for sustainability is the need of the hour.

- Digitization itself is creating some environmental issues like e-waste ,consumption of more electricity, these also needs to be factored in research on digitization and sustainability.

\section{$\underline{\text { References }}$}

1. Adi Kuntsman \& Imogen Rattle.(2019):Towards a Paradigmatic Shift in Sustainability Studies: A Systematic Review of Peer Reviewed Literature and Future Agenda Setting to Consider Environmental (Un)sustainability of Digital Communication. Environmental communication. Volume 13 ,issue 5. https://doi.org/10.1080/17524032.2019.1596144.

2. Ang Liu, Qinghua Zhu \&Stefan Seuring.(2020).New technologies in operations and supply chains: Implications for sustainability. International Journal of Production Economics. Volume 229,https://doi.org/10.1016/j.ijpe.2020.107889. 
3. Carmen Isensee, Frank Teuteberg, Kai-Michael Gries e\& Corrado Top.(2020).: The relationship between organizational culture, sustainability, and digitalization in SMEs: A systematic review. Journal of cleaner Production. Volume 275. Https://doi.org/10.1016/j.jclepro.2020.122944.

4. Denis Roegel.: Sustainable digitization. [Research Report] LORIA - Université de Lorraine. 2012. ffhal02340532f

5. Federica Ricci, Vincenzo Scafarto, Salvatore Ferr \& Alberto Tron.(2020), Value relevance of digitalization: The moderating role of corporate sustainability. An empirical study of Italian listed companies. Journal of Cleaner Production. Volume 276. https://doi.org/10.1016/j.jclepro.2020.123282.

6. Marlen Gabriele Arnold \& Anne Fischer .(2019) .Digitization and Sustainability: Threats, Opportunities, and Trade-Offs. Responsible, Sustainable, and Globally Aware Management in the Fourth Industrial Revolution .Pages 28. DOI: 10.4018/978-1-5225-7638-9.ch001.

7. https://www.igi-global.com/chapter/digitization-and-sustainability/227813

8. Middleton, K. (2005), "Collaborative digitization programs: a multifaceted approach to sustainability", Library Hi Tech, Vol. 23 No. 2, pp. 145-150.Emerald group publishing ltd.

9. Morteza Ghobakhloo.(2020). Industry 4.0, digitization, and opportunities for sustainability,

10. Journal of Cleaner Production, Volume 252. https://doi.org/10.1016/j.jclepro.2019.119869.

11. Müller, J.M.; Kiel, D.; Voigt, K.-I. What Drives the Implementation of Industry 4.0? The Role of Opportunities and Challenges in the Context of Sustainability. Sustainability 2018, 10, 247. https://doi.org/10.3390/su10010247

12. Opazo-Basáez M, Vendrell-Herrero F, Bustinza OF. Uncovering Productivity Gains of Digital and Green Servitization: Implications from the Automotive Industry. Sustainability. 2018; 10(5):1524.

13. Parida V, Sjödin D, Reim W. Reviewing Literature on Digitalization, Business Model Innovation, and S ustainable Industry: Past Achievements and Future Promises. Sustainability. 2019; 11(2):391.

14. R. R. Sharma, S. Mukherj i: Management of Permanent change. ISBN 978-3-658-05013-9 ISBN 9783-658-05014-6 (eBook) DOI 10.1007/978-3-658-05014-6 Library of Congress Control Number: 2014956666 Springer New York Heidelberg Dordrecht London

15. Sanders ,Boone, Ganesan \& Wood (2019).Sustainable Supply Chains in the Age of AI and Digitization: Research Challenges and Opportunities. Journal of business logistics. Vol.40,Issue 3.https://onlinelibrary.wiley.com/doi/abs/10.1111/jbl.12224

16. Stefan Seidel, Jan Recker and Jan vom Brocke. : Sensemaking and Sustainable Practicing: Functional Affordances of Information Systems in Green Transformations. MIS Quarterly, pp. 1275-1299 (25 pages).

17. Yasanur Kayikci .(2018).Sustainability impact of digitization in logistics. Procedia Manufacturing. Volume 21,2018,Pages 782-789,ISSN 2351-9789. 